\title{
STATUS HUKUM PENGUASAAN HAK ATAS TANAH OLEH WARGA NEGARA ASING YANG DIPEROLEH MELALUI PELELANGAN OBYEK HAK TANGGUNGAN
}

\author{
LEGAL STATUS OF MASTERY OF LAND RIGHTS BY FOREIGN \\ CITIZEN OBTAINED THROUGH THE AUCTION OF THE \\ MORTGAGE OBJECT
}

\author{
Widia Ulan Dini, Sudiarto \& Aris Munandar \\ Magister Kenotariatan Universitas Mataram \\ Email: widiaulandini@yahoo.co.id
}

Naskah diterima : 17/07/2017; revisi : 27/07/2017; disetujui : 30/08/2017

\begin{abstract}
The purpose of this research is to review and analyze the position of the position of the auction treaty as evidence of the transfer of land ownership rights for foreigners and to know and analyze the legal status of the occupation of land rights by foreigners acquired through the auction of the mortgage object..Based on research result; (1). The position of the auction made by the auctioneer may be used as a evidence of the transfer of holder house for Foreign Citizens, terminology with the provisions of Article 41 of the Government Regulation Number 24 of 1997 concerning Land Registration; (2) Legal Status of Land Rights Control by Foreign Citizens Obtained by the Object of the Rights The number of citizens of the state can be acquired through the status of use of rights, the land tenure with the shall be done through the procedures of change of rights
\end{abstract}

Key Words : Law Status, Land Tenure Control, Foreigner.

AbSTRAK

Tujuan dari penelitian ini adalah untuk mengkaji dan menganalisis tentang Kedudukan akta risalah lelang sebagai bukti peralihan hak milik atas tanah bagi warga negara asing dan untuk mengkaji dan menganalisis Status hukum penguasaan hak atas tanah oleh warga negara asing yang diperoleh melalui pelelangan obyek hak tanggungan. Tipe penelitian hukum ini adalah penelitian hukum Normatif.. Metode pendekatan yang digunakan adalah pendekatan Perundang-Undangan, dan pendekatan konseptual. Berdasarkan hasil penelitian ; (1). Kedudukan akta Risalah lelang sebagai bukti peralihan hak milik atas tanah bagi Warga Negara Asing yakni akta risalah lelang yang dibuat oleh Pejabat Lelang dapat dijadikan dasar bukti peralihan pendaftaran hak atas tanah bagi warga negara asing.; (2) Status Hukum Penguasaan Hak atas Tanah oleh Warga Negara Asing yang diperoleh melalui Pelelangan obyek Hak Tanggungan yakni warga negara asing tersebut dapat menguasai tanah yang diperolehnya dengan status penguasaan hak pakai, dimana status hak pakai atas nama warga negara asing tersebut harus dilakukan dengan prosedur perubahan hak.

Kata Kunci: Status Hukum, Penguasaan Tanah, Warga Negara Asing

\section{PENDAHULUAN}

Pemberian atau pembebanan Hak atas tanah berdasakan UUHT, terdiri dari subjek dan obyek. Subyek hak Tanggungan yaitu pemberi hak dan pemegang HT yakni dapat dilakukan oleh orang perorangan atau badan hukum asalkan mempunyai kewenangan untuk melakukan perbuatan hukum. Sedangkan Obyek hak tanggungan adalah hak atas tanah yang dapat dijadikan jaminan hutang atau agunan kredit yang terdiri dari Hak Milik (HM), Hak Guna 
Widia Ulan Dini, Sudiarto, Aris Munandar|Status Hukum Penguasaan Hak Atas Tanah Oleh........

Bangunan (HGB) dan Hak Pakai (HP) atas tanah.

Ketentuan Pasal 8 ayat (1) UUHT menentukan bahwa : "Pemberi HT adalah orang perseorangan atau badan hukum yang mempunyai kewenangan untuk melakukan perbuatan hukum terhadap objek HT yang bersangkutan". Selanjutnya didalam Pasal 9 Undang-undang Hak Tanggungan menyatakan bahwa :"Pemegang Hak Tanggungan adalah orang perseorangan atau badan hukum yang berkedudukan sebagai pihak yang berpiutang."

Ketentuan Pasal 9 UUHT memberikan peluang bagi Warga Negara Asing untuk bertindak dan berkedudukan sebagai pemegang hak Tanggungan, hal tersebut terjadi karena tidak ada persyaratan khusus mengenai pemegang Hak Tanggungan, sehingga orang perorangan atau badan hukum yang dimaksud dalam Pasal 9 bisa saja orang perseorangan dapat pula suatu badan hukum dan bahkan dapat dalam bentuk badan hukum asing yang berkedudukan di Indonesia maupun di luar negeri, sepanjang kredit yang bersangkutan dipergunakan untuk kegiatan usaha di wilayah negara Indonesia sebagaimana dalam ketentuan Pasal 10 UUHT. Hal tersebut berarti orang asing dapat bertindak sebagai subjek (pemegang Hak Tanggungan).

Terkait dengan penguasaan dan kepemilikan objek Hak Tanggungan yakni Penjelasan Pasal 12 Undang-undang Hak Tanggungan menyatakan bahwa :

"Ketentuan ini diadakan dalam rangka melindungi kepentingan debitor dan pemberi Hak Tanggungan lainnya, terutama jika nilai obyek Hak Tanggungan melebihi besarnya utang yang dijamin. Pemegang Hak Tanggungan dilarang untuk secara serta merta menjadi pemilik obyek Hak Tanggungan karena debitor cidera janji. Walaupun demikian tidaklah dilarang bagi pemegang Hak Tanggungan untuk menjadi pembeli obyek Hak Tanggungan asalkan melalui prosedur yang diatur dalam Pasal 20."

Dalam Pasal 20 ayat (1) huruf b menyatakan secara umum menyatakan bahwa apabila debitur cidera janji, maka pemegang hak tanggungan dapat melakukan penjualan obyek hak tanggungan melalui pelelangan umum untuk pelunasan piutang pemegang Hak Tanggungan dengan hak mendahulu dari pada kreditor-kreditor lainnya. Didalam Akta Pemberian Hak Tanggungan (APHT) juga terdapat janjijanji yang tertuang di dalamnya. Salah satu janji-janji tersebut menyatakan bahwa :

"Jika debitur tidak memenuhi kewajiban untuk melunasi hutangnya, berdasarkan perjanjian utang piutang tersebut diatas, oleh pihak pertama, pihak kedua selaku pemegang hak tanggungan peringkat pertama, dengan akta ini diberi dan menyatakan menerima kewenangan, dan untuk itu kuasa, untuk tanpa persetujuan terlebih dahulu dari pihak pertama: menjual atau suruh menjual di hadapan umum secara lelang obyek hak tanggungan baik seluruhnya maupun sebagian-bagian;".

Makna yang terkandung dalam salah satu perjanjian di dalam Akta pemberian hak tanggungan tersebut, memberikan kewenangan kepada pihak kreditur atau pemegang hak tanggungan yakni warga negara asing untuk menjual jaminan obyek hak tanggungan yang dikuasainya melalui proses pelelangan.

Sehingga di dalam penjelasan Pasal 12 Undang-Undang Hak tanggungan dan Pasal 1 angka 22 Peraturan Menteri Keuangan Nomor 27/PMK.06/2016 tentang Petunjuk Pelaksanaan Lelang tidak ada persyaratan khusus yang mengatur mengenai pembeli obyek Hak Tanggungan, sehingga hal tersebut memberikan ruang bagi WNA untuk menjadi pembeli obyek hak tanggungan, yang dikarenakan apabila 
pemberi hak tanggungan cidera janji, maka warga negara asing selaku pemegang hak tanggungan dengan adanya sertipikat hak tanggungan dapat bertindak selaku pembeli obyek hak tanggungan melalui suatu pelelangan dan jika dinyatakan sebagai pemenang lelang, maka nama siapa yang akan tercantum di dalam akta risalah lelang, karena didalam Pasal 41 ayat 1 Peraturan Pemerintah Nomor 24 Tahun 1997 tentang Pendaftaran Tanah menyatakan bahwa: "Peralihan hak melalui pemindahan hak dengan lelang hanya dapat didaftar jika dibuktikan dengan kutipan risalah lelang yang dibuat oleh pejabat lelang".

Kutipan risalah lelang tersebut sudah merupakan bukti peralihan hak atas tanah, layaknya akta jual beli dalam perbuatan hukum jual beli tanah. Dalam hal memerlukan tanah, dari ketentuan hukumnya tidak banyak yang mengetahui cara bagaimana memperolehnya dan apa yang menjadi alat buktinya. Jika tanah yang bersangkutan berstatus hak milik maka akan mudah untuk diketahui bahwa tanah yang bersangkutan boleh dikuasai dan digunakan tanpa batas waktu. ${ }^{1}$ Peralihan hak milik atas tanah salah satunya dapat dilakukan melalui pelelangan umum. Akibat hukum dengan penjualan secara lelang, apabila Warga Negara Asing sebagai pemenang lelang maka akan menerima penyerahan "hak milik" dari obyek lelang yang merupakan obyek hak tanggungan, sementara di sisi lain menentukan bahwa sistem hukum pertanahan di Indonesia menganut prinsip atau asas Nasionalitas.

Makna asas Nasionalitas adalah Warga negara asing tidak diperbolehkan untuk memperoleh hak milik atas tanah di Indonesia atau dengan kata lain; "Hanya warga negara indonesia saja yang dapat mempunyai hak milik atas tanah di Indonesia". Hal tersebut sebagaimana yang

${ }^{1}$ Rosandi, Baiq Henni Paramita. "Akibat Hukum Jual Beli Hak Atas Tanah Yang Belum Didaftarkan." Jurnal IUS (Kajian Hukum dan Keadilan) 4.3 (2016). hlm. 424. ditentukan dalam Pasal 21 dan Pasal 26 ayat (2) UUPA. Jika warga negara asing tidak boleh mempunyai hak milik atas tanah, maka apakah warga negara asing akan diberikan status penguasaan tanah yang diperoleh melalaui lelang dengan hak pakai atau hak-hak yang lainnya. Hal ini tentu dapat menimbulkan persoalan-persoalan tentang ketidakpastian hukum dan ketidakserasian mengenai aturan-aturan yang mengatur tentang penguasaan tanah bagi warga negara asing yang diperoleh melalui suatu pelelangan obyek hak tanggungan.

Rumusan masalah yang saya gunakan; Bagaimanakah Kedudukan akta Risalah lelang sebagai bukti peralihan hak milik atas tanah bagi Warga Negara Asing?; Bagaimanakah Status Hukum Penguasaan Hak atas Tanah oleh Warga Negara Asing yang diperoleh melalui Pelelangan obyek Hak Tanggungan?

Penelitian Tesis ini menggunakan penelitian Hukum Normatif yaitu : penelitian yang dilakukan berdasarkan Peraturan Perundang-Undangan yang berlaku dan menjadikan data lapangan sebagai penunjang dengan menggunakan pendekatan Perundang-Undangan dan pendekatan konseptual, tekhnik pengumpulan bahan hukum menggunakan tekhnik studi dokumen dengan menggunakan analisis penafsiran Ekstensif sebagai analisis bahan hukum.

\section{PEMBAHASAN}

Kedudukan Akta Risalah Lelang sebagai bukti Peralihan Hak Milik atas tanah bagi Warga Negara Asing

\section{Pengertian Lelang Hak atas Tanah}

Eksistensi Unit Lelang Negara dimulai sejak tahun 1908, yaitu dengan berlakunya Peraturan Lelang (Vendu Reglement) Stb. 1908 - 189 dan Instruksi Lelang (Vendu Instructie) Stb. 1908 - 190. Sejak semula Unit Lelang berdiri sendiri sebagai Inspeksi 
Widia Ulan Dini, Sudiarto, Aris Munandar|Status Hukum Penguasaan Hak Atas Tanah Oleh........

urusan Lelang di Lingkungan Departemen Keuangan. ${ }^{2}$

Di dalam pasal 1 angka 1 Peraturan Menteri Keuangan Nomor27/PMK.06/2016 tentang Petunjuk Pelaksanaan Lelang menyatakan bahwa : "Lelang adalah penjualan barang yang terbuka untuk umum dengan penawaran harga secara tertulis dan/ atau lisan yang semakin meningkat atau menurun untuk mencapai harga tertinggi, yang di dahului dengan Pengumuman Lelang."

\section{Subyek Penjualan Lelang Hak atas Tanah}

Dalam pelaksanaan penjualan secara lelang terdapat beberapa subyek yang secara langsung terkait dengan pelaksanaan penjualan secara lelang yaitu :

\section{Pejabat Lelang}

Pengertian Pejabat Lelang menurut Pasal 1 angka 14 Peraturan Menteri Keuangan Nomor 27/PMK.06/2016 tentang Petunjuk Pelaksanaan Lelang menyatakan bahwa: "Pejabat Lelang adalah orang yang berdasarkan Peraturan Perundang-Undangan diberi wewenang khusus untuk melaksanakan penjualan barang secara lelang."

2. Pemohon/ penjual lelang

Pemohonlelang/penjuallelangadalah orang atau badan hukum atau instansi atau usaha yang berdasarkan Peraturan Perundang-Undangan atau perjanjian berhak untuk menjual barang secara lelang, dan mengajukan permohonan kekantor lelang agar barang yang dimiliki/ dikuasai dapat dilelang.

\section{Peserta lelang}

2 Sutardjo,Pelelangan Dalam Rangka Eksekusi Oleh Pengadilan Negeri dan Pelelangan Oleh PUPN serta Aspek-Aspek Hukumnya Yang Timbul Dalam Praktek, Jakarta, $1994 \mathrm{Hlm} 4$.
Peserta lelang adalah perorangan atau badan hukum/badan usaha yang memenuhi syarat menjadi peserta/ pembeli lelang kecuali yang nyata-nyata dilarang Pasal 77 Peraturan Menteri Keuangan Republik Indonesia No.27/ PMK.06/2016 seperti: Hakim, Jaksa, Panitera, Pengacara, Pejabat Lelang, Juru Sita, Notaris, yang terkait dalam pelaksanaan lelang.

4. Pembeli Lelang

Pembelilelangadalahorangataubadan yang mengajukan penawaran tertinggi yang mencapai atau melampaui nilai limit yang disahkan sebagai pemenang lelang oleh Pejabat Lelang.

\section{Kedudukan Warga Negara Asing sebagai Peserta Lelang Hak atas Tanah}

Peserta lelang merupakan terjemahan dari istilah attendetrs, bidders, the righest bidders, buyers atau purchasers yang artinya bisa peserta, penawar, penawaran tertinggi/ pemenang lelang, atau pembeli lelang. Kalau peserta lelang adalah orang atau badan hukum/badan usaha yang mengajukan penawaran tertinggi dan disahkan sebagai pemenang lelang oleh Pejabat Lelang. ${ }^{3}$

Setiap orang atau badan hukum atau badan usaha dapat menjadi peserta lelang. Namun ada subjek hukum yang di larang menjadi peserta lelang, yakni mereka yang terkait secara langsung di dalam proses pelelangan sebagaimana yang diatur dalam Pasal 77 Peraturan Menteri Keuangan Nomor 27/PMK.06/2016 tentang Petunjuk Pelaksanaan Lelang diantaranya adalah:

(1)Pihak-pihakyangdilarangmenjadiPeserta Lelang adalah:

a. Pejabat Lelang dan keluarga sedarah dalam gens lurus ke atas dan ke bawah derajat pertama;

${ }^{3}$ Rachmadi Usman, Hukum Lelang, Sinar Grafika, Jakarta, 2016,hlm. 63 
b. Suami atau istri serta saudara sekandung Pejabat Lelang;

c. Pejabat Penjual;

d. Pemandu Lelang;

e. Hakim;

f. Jaksa;

g. Panitera;

h. Juru Sita;

i. Pengacara atau Advokat;

j. Notaris;

k. Pejabat Pembuat Akta Tanah;

1. Penilai;

m. Pegawai DJKN;

n. Pegawai Balai Lelang; dan

o. Pegawai Kantor Pejabat Lelang Kelas II, yang terkait langsung dengan proses lelang.

(2)Selain pihak-pihak yang dimaksud pada ayat (1), pada pelaksanaan Lelang Eksekusi, pihak tereksekusi/ debitor/ tergugat/terpidana yang terkait dengan lelang dilarang menjadi Peserta Lelang.

Berdasarkan Pasal 77 Peraturan Menteri Keuangan Nomor 27/PMK.06/2016 tentang Petunjuk Pelaksanaan Lelang mengenai pihak-pihak yang dilarang menjadi peserta lelang, maka dapat dikemukakan bahwa dalam pasal tersebut tidak ada larangan bagi Warga Negara Asing untuk menjadi peserta lelang, dari ketentuan peraturan yang ada dapat disimpulkan bahwa WNA dapat menjadi peserta lelang.

Berdasarkan hasil wawancara dengan kepala KPKLN (Kantor Pelayanan Kekayaan Negara dan Lelang) di Kota Mataram, menyatakan bahwa jika warga negara asing yang mengikuti lelang sebagai peserta lelang obyek hak tanggungan berupa tanah (benda tidak bergerak), maka prosedur pelaksanaan lelang yang dilaksanakan bagi Warga Negara Asing sama dengan prosedur pelaksanaan lelang yang dilakukan untuk Warga Negara Indonesia yang ikut menjadi peserta lelang, asalkan WNA tersebut mempunyai NPWP ( Nomor Pokok Wajib Pajak) khusunya bagi benda tidak bergerak atau tanah. ${ }^{4}$

Untuk dapat memiliki NPWP maka WNA harus tunduk pada Pasal 6 Peraturan Direktur Jenderal Pajak Nomor PER-38/ PJ/2013 tentang Perubahan atas Peraturan Direktur Jenderal Pajak Nomor PER-20/ PJ/2013 tentang Tata Cara Pendaftaran dan Pemberian Nomor Pokok Wajib Pajak, Pelaporan Usaha, dan Pengukuhan Pengusaha Kena Pajak, Penghapusan Nomor Pokok Wajib Pajak, dan Pencabutan Pengukuhan Pengusaha Kena Pajak, serta Perubahan Data dan Pemindahan Wajib Pajak,

\section{Lelang Atas Dasar Perjanjian Hak Tang- gungan}

Lelang atas dasar perjanjian hak tanggungan dikarenakan adanya Akta Pemberian Hak Tanggungan yang dibuat oleh PPAT. Pelaksanaan eksekusi lelang obyek hak tanggungan yang didasari pada pembuatan APHT (Akta Pemberian Hak Tanggungan), dan di dalam APHT ada tercantum klausula yang sifatnya fakultatif menyatakan bahwa:

"Jika debitur tidak memenuhi kewajiban untuk melunasi hutangnya, berdasarkan perjanjian utang piutang tersebut diatas, oleh pihak pertama, pihak kedua selaku pemegang hak tanggungan peringkat pertama, dengan akta ini diberi dan menyatakan menerima kewenangan, dan untuk itukuasa, untuk tanpa persetujuan terlebih dahulu dari pihak pertama: menjual atau suruh menjual di hadapan umum secara lelang obyek hak tanggungan baik seluruhnya maupun sebagian"

\footnotetext{
${ }^{4}$ Wawancara dengan Pejabat Lelang KPKNL di Kota Mataram pada tanggal 17 Februari tahun 2017
} 
Maka dengan adanya klausula tersebut berarti secara tersirat apabila debitur wanprestasi, maka kreditur warga negara asing selaku pemegang hak tanggungan dapat mengekskusi obyek hak tanggungan dengan kekuasaan sendiri dengan memohon pelaksanaan lelang melalui kantor lelang. Pembuatan APHT atas nama warga negara asing sebagai pemegang hak tanggungan merupakan suatu perbuatan hukum yang dilakukan oleh PPAT. Menurut Pasal 9 Undang-Undang hak tanggungan tidak ada larangan bagi WNA sebagai pemegang hak tanggungan, dengan dasar hukum tersebut PPAT dapat melakukan perbuatan hukum berupa pembuatan Akta Pemberian Hak Tanggungan dengan atas nama Warga Negara Asing selaku pemegang hak Tanggungan.

\section{Kedudukan Akta Risalah Lelang Sebagai Bukti Peralihan Hak Milik Atas Tanah Bagi Warga Negara Asing.}

Keberadaan Akta Risalah Lelang sangat penting dalam proses lelang baik bagi Penjual Lelang maupun Pembeli Lelang kerena menyangkut kebutuhan bukti kepemilikan yang sah terhadap objek yang dilelang baik benda bergerak maupun tak bergerak. Kekuatan pembuktian Akta Risalah Lelang yaitu terdiri dari kekuatan pembuktian lahir, formil, dan materiil sebagaimana sesuai dengan Pasal 1868 Kitab Undangundang Hukum Perdata. Apabila peserta lelang dinyatakan sebagai pemenang lelang atau pembeli, maka pembeli tersebut akan mendapatkan salinan dari Akta Risalah Lelang tersebut. Hal tersebut dinyatakan dalam Pasal 94 Peraturan Menteri Keuangan Nomor 27/PMK.06/2016 tentang Petunjuk Pelaksanaan Lelang.

Dalam hal ini juga berdasarkan wawancara dengan Kepala Kantor KPKLN Kota Mataram menyatakan bahwa apabila Warga Negara Asing sebagai peserta lelang dan dinyatakan sudah memenuhi syaratsyarat sebagai peserta lelang sebagaimana yang telah disebutkan diatas, lalu peserta lelang tersebut dinyatakan sebagai pembeli serta pemenang lelang objek Hak Tanggungan maka dalam akta Risalah lelang akan tercantum nama warga negara asing tersebut, dikarenakan bahwa Akta Risalah lelang yang dibuat oleh pejabat lelang harus berdasarkan fakta, keadaan, dan kenyataan yang sebenarnya terjadi di lapangan atau pada saat pelaksanaan lelang,setelah itu warga negara asing sebagai pembeli atau pemenang lelang selanjutnya harus mengurus sendiri mengenai status hukum tanah yang diperolehnya ke instansi Badan Pertanahan Nasional setempat untuk melakukan pendaftaran obyek lelang guna memenuhi asas publisitas sesuai dengan ketentuan peraturan Perundang-Undangan yang berlaku. ${ }^{5}$

Dengan telah dibuatnya risalah lelang oleh Pejabat dari Kantor Lelang, maka pada saat itu telah terjadi pemindahan hak atas tanah atau Hak Milik atas satuan Rumah susun dari pemegang hak nya semula sebagai penjual lelang kepada pihak lain sebagai pembeli lelang. Namun pemindahan hak tersebut hanyalah diketahui oleh kedua belah pihak, pihak ketiga tidak mengetahui tentang adanya lelang tersebut. Agar pihak ketiga mengetahuinya, maka lelang tersebut harus didaftarkan ke Kantor Pertanahan Kabupaten/Kota setempat karena pendaftaran tanah mempunyai sifat terbuka. Dengan pendaftaran pemindahan hak ke Kantor Pertanahan Kabupaten/Kota, maka terpenuhilah asas publisitas dalam pendaftaran tanah yaitu setiap orang dapat mengetahui data fisik berupa letak, ukuran, batas-batas tanah, dan data yuridis berupa subyek hak, status hak, dan pemindahan hak atas tanah atau Hak Milik atas satuan rumah susun yang bersangkutan ke Kantor Pertanahan Kabupaten/Kota. ${ }^{6}$

\footnotetext{
Wawancara dengan Kepala Kantor KPKNL Mataram pada tanggal 17 Februari 2017

${ }^{6}$ Urip Santoso, Pendaftaran dan Peralihan Hak atas Tanah, Kencana Prenada, Media Group,2013, hlm. 388
} 
Menurut penulis dengan adanya Akta Pemberian Hak Tanggungan (APHT) dimana kedudukan WNA Sebagai pemegang hak tanggungan dapat mengeksekusi obyek hak tanggungan apabila debitur wanprestasi dan dapat dilakukan penjualan obyek hak tanggungan tersebut melalui proses pelelangan, hal tersebut sebagaimana tercantum didalam janji-janji didalam APHT tersebut, selain itu didalam penjelasan pasal 12 UUHT juga menyatakan bahwa:

"Ketentuan ini diadakan dalam rangka melindungi kepentingan debitor dan pemberi Hak Tanggungan lainnya, terutama jika nilai obyek Hak Tanggungan melebihi besarnya utang yang dijamin. Pemegang Hak Tanggungan dilarang untuk secara serta merta menjadi pemilik obyek Hak Tanggungan karena debitor cidera janji. Walaupun demikian tidaklah dilarang bagi pemegang Hak Tanggungan untuk menjadi pembeli obyek Hak Tanggungan asalkan melalui prosedur yang diatur dalam Pasal 20.”

Berdasarkan penjelasan pasal 12 UUHT tersebut maka dapat dijelaskan bahwa UUHT telah memberikan ruang atau peluang kepada WNA untuk dapat menguasai tanah hak milik di Indonesia yang dikarenakan WNA dapat dijadikan sebagai peserta dan pembeli lelang, ketika WNA dapat menjadi sebagai peserta dan pembeli lelang dan kemudian dinyatakan sebagai pemenang lelang, maka dengan adanya Kutipan akta Risalah lelang tersebut, Warga Negara Asing dapat melakukan pendaftaran hak atas tanah ke kantor Badan Pertanahan Nasional dengan akta risalah lelang sebagai dasar telah terjadi peralihan hak atas tanahnya.

Dan dikaitkan dengan Teori Kewenangan menurut para ahli atau Kalangan doktrinal yang memberikan pengertian sebagai perumusan makna wewenang tersebut. Para ilmuan hukum di bidangnya seperti: ${ }^{7}$

1. H.D.Stout, wewenangadalahkeseluruhan aturan-aturan yang berkenaan dengan perolehan dan penggunaan wewenang pemerintah oleh subyek hukum publik dalam hubungan hukum publik.

2. FPCL. Tonnaer, kewenangan pemerintah dalam kaitan ini dianggap sebagai kemampuan untuk melaksanakan hukum positif, dan dengan begitu, dapat diciptakan hubungan hukum antara pemerintah dengan warga negara.

3. Indoharto, wewenang sebagai suatu kemampuan yang diberikan oleh suatu peraturan perundang-undangan yang berlaku untuk menimbulkan akibatakibat hukum yang sah.

4. Bagir Manan, wewenang sekaligus berarti hak dan kewajiban.

Maka dalam hal ini KPKLN telah menjalankan tugas dan fungsinya sebagai lembaga yang memiliki kewenangan untuk melakukan dan melaksanakan suatu pelelangan, tentunya kewenangan KPKLN dalam melaksanakan suatu pelelangan merupakan suatu upaya tindakan dari pemerintah berdasarkan Undang-Undang agar tercapainya keadilan dan kesejahteraan serta tertib administrasi dalam pelaksanaan suatu pelelangan oleh lembaga pemerintah yakni lembaga KPKLN.

Status Hukum Penguasaan Hak atas Tanah oleh Warga Negara Asing yang diperoleh melalui Pelelangan obyek Hak Tanggungan

\section{Peralihan hak Atas Tanah Yang Di- peroleh Melalui Lelang}

Peralihan hak atas tanah menyebabkan hak atas tanah beralih dari seseorang kepada

${ }^{7}$ Lukman Hakim, Kedudukan Hukum Komisi Negara di Indonesia, Program Pasca Unibraw, Malang, 2010, hlm. 52 
Widia Ulan Dini, Sudiarto, Aris Munandar|Status Hukum Penguasaan Hak Atas Tanah Oleh........

orang lain. Jadi, peralihan merupakan suatu perbuatan hukum yang sengaja dilakukan dengan tujuan agar hak atas tanah berpindah dari yang mengalihkan kepada yang menerima pengalihan.

Pasal 37 ayat (1) dan pasal 41 ayat (1) Peraturan Pemerintah Nomor 24 Tahun 1997 Tentang Pendaftaran Tanah , menegaskan bahwa:

"Peralihan hak atas tanah dan hak milik atas satuan rumah susun melalui jual beli, tukar menukar, hibah, pemasukan data perusahaan dan perbuatan hukum pemindahan hak lainnya, kecuali pemindahan hak melalui lelang hanya dapat didaftarkan jika dibuktikan dengan akta yang dibuat oleh PPAT yang berwenang menurut ketentuan peraturan perundangUndangan yang berlaku."

Pada pasal 41 ayat (1) PP 24 tahun 1997 menyatakan bahwa: "Peralihan hak melalui pemindahan hak dengan lelang hanya dapat didaftar jika dibuktikan dengan kutipan Risalah lelang yang dibuat oleh pejabat lelang.". Dalam peralihan hak atas tanah melalui pelelangan eksekusi hak Tanggungan bagi warga negara Asing maupun warga negara Indonesia harus didahului melalui prosedur lelang. Pelaksanaan prosedur lelang peralihan hak atas tanah bagi warga negara asing memiliki kesamaan dengan pelaksanaan prosedur lelang bagi warga negara indonesia, yakni harus mengikuti prosedur pelaksanaan lelang sebagaimana yang diatur dalam Peraturan Menteri Keuangan Nomor 27/PMK.06/2016 tentang Petunjuk Pelaksanaan Lelang.

\section{Larangan Penguasaan Hak Milik atas tanah bagi Warga Negara Asing}

Pengertian "penguasaan" dan "menguasai" dapat diartikan dalam bentuk fisik dan yuridis yang memiliki aspek perdata dan beraspek publik Ketentuan didalam
Pasal 33 ayat (3) UUD 1945 menunjukan bahwa Negara Indonesia adalah negara yang mengamanatkan penguasaan negara atas bumi, air dan kekayaan alam didalamnya dan menggunakannya untuk sebesar-besarnya kemakmuran rakyat. Berdasarkan ketentuan Pasal 33 ayat (3) UUD 1945 tersebut maka Hukum Tanah Nasional harus sesuai dengan kepentingan rakyat. Sebagaimana dikatakan oleh Boedi Harsono :

"Hukum Tanah Nasional sudah barang tentu harus sesuai dengan kepentingan rakyat, artinya rakyat Indonesia. Bukan hanya rakyat orang-seorang atau golongan-golongan, apalagi rakyat asing. Hukum Tanah Nasional tidak diadakan untuk menjamin kepentingan orang-orang asing atau modal asing, seperti Agrarische Wet dulu." 8

Prinsip Nasionalitas tercermin dalam Pasal 21 ayat (1) dan ayat (2) UndangUndang Pokok Agraria, yang masingmasing berbunyi:

1. Hanya Warga Negara Indonesia dapat mempunyai hak milik;

2. Oleh Pemerintah ditetapkan badan badan hukum yang dapat mempunyai hak milik dan syarat-syaratnya."

Hal tersebut berarti bahwa perseorangan yang bukan Warga Negara Indonesia tidak dapat mempunyai Hak Milik atas tanah di Indonesia atau Warga Negara Asing tidak dapat menjadi subyek Hak Milik. Sehingga Pasal tersebut berkesesuaian dengan kepentingan rakyat Indonesia. Penguasaan tanah secara yuridis dilandasi oleh hak yang dilindungi oleh hukum dan memberi kewenangan kepada pemegang hak untuk menguasai secara fisik tanah tertentu. Sekalipun penguasaan yuridis memberi kewenangan untuk

${ }^{8}$ Boedi Harsono, Hukum Agraria Indonesia, Sejarah Pembentukan Undang-Undang Pokok Agraria, isi dan pelaksanaannya, Djambatan, 2008, hlm. 167. 
menguasai tanah yang secara fisik namun pada kenyataannya penguasaan fisiknya dilakukan pihak lain. Misalnya, apabila tanah yang dikuasai disewakan kepada pihak lain, maka tanah tersebut dikuasai secara fisik oleh pihak lain dengan hak sewa.

Dalam hal ini pemilik tanah berdasarkan hak penguasaan yuridisnya, berhak untuk menuntut diserahkannya kembali tanah yang bersangkutan secara fisik kepadanya. Dalam hukum tanah penguasaan yuridis yang tidak memberi kewenangan untuk menguasai tanah yang bersangkutan secara fisik. Kreditor pemegang hak jaminan atas tanah mempunyai hak penguasaan yuridis atas tanah yang dijadikan agunan, tetapi penguasaannya secara fisik tetap ada pada yang mempunyai tanah. Hak penguasaan atas tanah apabila sudah dihubungkan dengan tanah orang (badan hukum) tertentu, maka yang dimaksud dengan hak penguasaan atas tanah adalah hak penguasaan yang didasarkan pada suatu hak maupun suatu kuasa yang pada kenyataannya memberikan wewenang untuk melakukan perbuatan hukum sebagaimana layaknya orang yang mempunyai hak. ${ }^{9}$

Terhapusnya Hak milik karena dikuasai atau dialihkan kepada subjek Hukum yang tidak berhak memangku kedudukan hak milik atas tanah.

Dalam tatanan hukum pertanahan nasional, hubungan hukum antara orang baik Warga Negara Indonesia maupun Warga Negara Asing, serta perbuatan hukumnya terkait dengan tanah, telah diatur dalam Undang-Undang No. 5 Tahun 1960 tentang Peraturan Dasar PokokPokok Agraria (UUPA). Salah satu prinsip yang dianut oleh UUPA adalah prinsip nasionalitas.

Dalam hal memerlukan tanah, dari ketentuan hukumnya tidak banyak yang

\footnotetext{
${ }^{9}$ Ibid, hlm. 23
}

mengetahui carabagaimana memperolehnya dan apa yang menjadi alat buktinya. Jika tanah yang bersangkutan berstatus hak milik maka akan mudah untuk diketahui bahwa tanah yang bersangkutan boleh dikuasai dan digunakan tanpa batas waktu.

Pasal 27 Undang-Undang Pokok Agraria menetapkan faktor-faktor penyebab hapusnya hak milik atas tanah dan tanahnya jatuh kepada negara apabila : ${ }^{10}$

1. KarenapencabutanhakberdasarkanPasal 18 ;

2. Karena penyerahan dengan sukarela oleh pemiliknya;

3. Karena ditelantarkan;

4. Karena ketentuan Pasal 21 ayat 3 dan 26 ayat 2 .

Maka dari itu, bahwa berdasarkan ketentuan yang diatas, terutama ketentuan pasal 21 ayat 3 dan pasal 26 ayat 2 UUPA yang secara tersirat merupakan syarat mengenai subjek hak milik atas tanah, dengan demikian tidak ada pihak lain yang dapat mempunyai Hak Milik atas tanah. Ini berarti setiap orang atau badan hukum yang mempunyai Hak Milik atas tanah tidak begitu saja dapat melakukan pengalihan Hak Milik atas tanah yang dikuasainya tersebut. Hak Milik atas tanah hanya dapat dialihkan kepada Warga Negara Indonesia (WNI) atau kepada badan hukum Indonesia sebagaimana yang ditentukan dalam Peraturan Pemerintah No. 38 Tahun 1963 tentang Penunjukkan Badan-Badan Hukum yang Dapat Mempunyai Hak Milik Atas Tanah. Apabila syarat tersebut tidak terpenuhi maka Peralihan Hak Milik atas tanah, yang telah berpindah dan dikuasai oleh subyek yang tidak berhak baik secara langsung maupun tidak langsung kepada orang asing, kepada seseorang yang mempunyai dwi kewarganegaraan atau kepada badan hukum yang tidak ditunjuk

\footnotetext{
${ }^{10}$ Ibid, hlm. 98
} 
oleh pemerintah adalah Batal demi hukum artinya adalah dari semula dianggap tidak pernah ada dilahirkan suatu perjanjian dan tidak pernah ada suatu perikatan dan tanahnya jatuh kepada Negara, artinya tanahnya kembali menjadi tanah yang langsung dikuasai Negara.

Sementara itu menurut Maria S.W Sumardjono ketentuan mengenai persyaratan subyek hak, khususnya terhadap WNA, disertai dengan sanksi terhadap pelanggarannya sebagaimana dimuat dalam Pasal 26 ayat (2) UUPA. Pelanggaran terhadap ketentuan itu berakibat bahwa peralihan Hak Milik kepada WNA itu batal demi hukum dan hak atas tanahnya jatuh pada Negara. ${ }^{11}$

Hal tersebut dikarenakan Hak Milik merupakan hak yang terkuat dan terpenuh yang memberikan kewenangan kepada pemiliknya untuk memberikan kembali suatu hak lain di atas bidang tanah Hak Milik. Hak dimaksud dapat berupa Hak Guna Bangunan atau Hak Pakai, dengan pengecualian Hak Guna Usaha. Hal ini hampir sama dengan kewenangan Negara sebagai penguasa untuk memberikan tanah kepada warganya, ${ }^{12}$

Sehingga ditinjau dari Undang-Undang Pokok Agraria bahwa kepemilikan tanah yang dimiliki oleh orang asing khususnya hak milik tidak sah dan apabila terbukti secara sengaja melakukan perbuatan hukum yang menimbulkan terjadinya penyelundupan hukum maka kepemilikan tersebut dapat dibatalkan demi hukum. Peralihaan Hak Milik atas tanah dari Warga Negara Indonesia kepada Warga Negara Asing bertentangan dengan tujuan Negara hukum secara materiil yang dalam Teori Hukum menurut Utrecht disebut

${ }_{11}$ Maria S.W. Sumardjono, Kebijakan Pertanahan, Antara Regulasi Dan Implementasi, Penerbit Kompas, Jakarta, 2001, hlm.7

${ }^{12}$ Kartini Mulyadi dan Gunawan Wijaya, Hak-Hak Atas Tanah-Seri Hukum Harta Kekayaan, Kencana Jakarta, 2007, hlm.30 sebagai konsepsi Negara Kesejahteraan (welfare state). Salah satu tujuan Negara Kesejahteraan adalah melindungi Bangsa Indonesia dari dominasi bangsa asing dalam segala bidang, termasuk dalam bidang pertanahan.

Status Hukum Penguasaan Hak atas Tanah bagi Warga Negara Asing melalui Pelelangan Obyek Hak Tanggungan.

\section{Bagi Warga Negara Indonesia}

Prosedur Pelaksanaan pelelangan bagi warga negara indonesia dilaksanakan berdasarkan Peraturan Menteri Keuangan Nomor : 27/PMK.06/2016 tentang Petunjuk Pelaksanaan Lelang. Setelah melalui berbagai prosedur pelaksanaan lelang telah dilaksanakan sesuai ketentuan peraturan perundang-Undangan yang berlaku, maka warga negara indonesia dapat memperoleh segala macam hak atas tanah sebagaimana yang telah diatur dalam Pasal 16 ayat (1) Undang-Undang Nomor 5 Tahun 1960 Tentang Peraturan Dasar Pokok-Pokok Agraria.

Warga Negara Indonesia yang mengikuti proses pelelangan dan dinyatakan sebagai pemenang lelang, maka warga negara indonesia akan memperoleh akta Risalah lelang untuk selanjutnya dapat dijadikan dasar di dalam melakukan Pendaftaran hak atas tanah guna memenuhi asas publisitas. Warga Negara Indonesia yang telah memperoleh tanah melalui Pelelangan dapat memperoleh segala macam hak atas tanah sebagaimana yang diatur didalam UUPA. Hak-hak atas tanah yang telah diuraikan di atas hanya dapat diberikan bagi Warga Negara Indonesia secara keseluruhan khususnya juga mengenai Hak Milik atas Tanah yang dikarenakan warga negara indonesia merupakan subyek hukum yang berhak untuk memiliki tanah di Indonesia.

Berdasarkan hasil wawancara dengan Kepala Sub seksi Penetapan Tanah dan Instansi Pemerintah pada Kantor Badan 
Pertanahan Nasional Kota Mataram, apabila Warga Negara Indonesia ingin melakukan perubahan hak atas tanahnya dari status Hak Milik ke Hak Guna Bangunan atau Hak Pakai maka Warga Negara Indonesia tersebut harus mengikuti prosedur sebagaimana yang diatur di dalam Keputusan Menteri Agraria/ Kepala Badan Pertanahan Nasional No. 16 Tahun 1997 tentang Perubahan Hak Milik menjadi Hak Guna Bangunan atau Hak Pakai dan Hak Guna Bangunan menjadi Hak Pakai, yang mana sebelumnya harus dilengkapi dengan pengajuan permohonan dengan berbagai persyaratan dokumen.

\section{Bagi Warga Negara Asing}

Warga Negara Asing yang memperoleh tanah melalui Pelelangan dapat memperoleh akta risalah lelang, namun jika objek lelang yang diperoleh oleh berupa tanah dengan status hak milik, maka warga negara asing tersebut tidak dapat melakukan peralihan hak milik atas tanah dengan akta risalah lelang, yang dikarenakan dalam hukum tanah Nasional negara Indonesia, mengenal adanya asas Nasionalitas dan Warga negara Asing merupakan subjek Hukum yang tidak berhak memangku kedudukan hak milik atas tanah, akan tetapi akta risalah lelang yang diperoleh oleh Warga Negara Asing tersebut masih dapat untuk dijadikan dasar dalam memperoleh hak hak atas tanah selain hak milik.

Pada dasarnya setiap orang tanpa memperhatikan status kewarganegaraannya dapat mempunyai hak atas tanah, oleh karenanya WNA dapat mempunyai hak atas tanah di Indonesia, prinsip tersebut tercermin pada Pasal 4 ayat (1) UUPA, perbedaan hanya terjadi dalam hal macam hak atas tanah yang dapat dimiliki oleh seseorang. Hak atas tanah yang mengandung aspek kepastian hukum dan keadilan tidak terpisah dari penggunaan dan pemanfaatan tanah yang mewujudkan kemakmuran. Kepastian dan keadilan saja, tidak bisa mewujudkan kemakmuran tanpa penggunaan dan pemanfaatan. Sebaliknya penggunaan dan pemanfaatan saja tanpa kepastian dan keadilan tidak bisa memberikan kemakmuran yang adil dan berkepastian yang merupakan cita-cita kemerdekaan. ${ }^{13}$

Warga negara asing selaku kreditur atau pemegang hak tanggungan atas objek hak tanggungan berupa hak milik atas tanah yang dimiliki oleh warga negara indonesia, sehingga apabila telah diterbitkan sertifikat hak tanggungan oleh Badan Pertanahan Nasional maka apabila Warga Negara Indonesia melakukan ingkar janji atau wanprestasi, WNA selaku pemegang hak tanggungan dapat menjual obyek hak tanggungan melalui pelelangan. Hal ini sesuai dengan janji fakultatif yang terdapat didalam Akta Pemberian Hak Tanggungan yang menyatakan bahwa:

"Jika debitur tidak memenuhi kewajiban untuk melunasi hutangnya, berdasarkan perjanjian utang piutang tersebut diatas, oleh pihak pertama, pihak kedua selaku pemegang hak tanggungan peringkat pertama, dengan akta ini diberi dan menyatakan menerima kewenangan, dan untuk itu kuasa, untuk tanpa persetujuan terlebih dahulu dari pihak pertama: menjual atau suruh menjual di hadapan umum secara lelang obyek hak tanggungan baik seluruhnya maupun sebagian”.

Warga negara asing tersebut dapat melakukan permohonan pengajuan lelang terhadap objek hak tanggungan berdasarkan Akta Pemberian hak Tanggungan. Tentunya dalam hal ini, jika warga negara asing selaku pemegang hak tanggungan mengajukan pelaksanaan lelang ke kantor KPKLN, dan warga negara asing dapat pula untuk mendaftarkan diri sebagai peserta lelang bahkan dapat pula menjadi pembeli hal ini

13 Soedjarwo Soeromihardjo, Mengkritisi Undang-Undang Pokok Agraria, Cerdas Pustaka, Jakarta, 2009, hlm.125 
Widia Ulan Dini, Sudiarto, Aris Munandar|Status Hukum Penguasaan Hak Atas Tanah Oleh........

berdasarkan pernyataan dari penjelasan Pasal 12 UUHT.

Sehingga apabila dinyatakan sebagai pemenang lelang, warga negara asing tersebut akan memperoleh Kutipan Akta Risalah Lelang sebagai dasar pendaftaran peralihan hak milik atas tanah sebagaimana yang diatur di dalam Peraturan Pemerintah Nomor 24 Tahun 1997 tentang Pendaftaran Tanah. Akan tetapi telah diatur secara jelas dalam Hukum tanah nasional yakni dalam UUPA Nomor 5 Tahun 1960 yang menyatakan bahwa hanya Warga Negara Indonesia saja yang berhak untuk memiliki tanah dengan hak milik di wilayah Indonesia dan secara tegas melarang orang asing atau WNA untuk dapat mempunyai Hak Milik atas tanah.

Sebagaimana yang telah dikemukakan di atas mengenai jenis-jenis hak atas tanah, maka jenis hak atas tanah dengan Hak Milik hanya dapat di miliki oleh WNI saja, sedangkan Warga negara asing tidak dapat memiliki tanah di Indonesia, melainkan warga negara asing setelah dinyatakan sebagai pemenang lelang dan mendapatkan akta risalah lelang sebagai dasar pendaftaran perubahan hak milik menjadi hak pakai di Kantor Badan Pertanahan Nasional. Dalam hal pengaturan mengenai perubahan hak milik menjadi hak pakai, maka sesuai ketentuan peraturan yang berlaku yangdiatur dalam Keputusan Menteri Agraria/ Kepala Badan Pertanahan Nasional No. 16 Tahun 1997 tentang Perubahan Hak Milik menjadi Hak Guna Bangunan atau Hak Pakai dan Hak Guna Bangunan menjadi Hak Pakai. Ketentuan ini dibuat dengan tujuan untuk mengakomodir kemungkinan terjadinya peralihan hak atas tanah tertentu kepada pihak yang tidak dapat menjadi atau bukan subjek hukum yang diperkenankan untuk menguasai tanah dengan hak atas tanah.

Berdasarkan hasil wawancara dengan Kepala Sub seksi Hak Tanah dan Penetapan tanahpada Kantor Badan Pertanahan Nasional Kota Mataram menyatakan bahwa untuk merubah status hak milik menjadi hak pakai bagi warga negara asing tersebut harus mengikuti ketentuan prosedur perubahan hak milik ke hak pakai sebagaimana yang diatur didalam Keputusan Menteri Agraria/ Kepala Badan Pertanahan Nasional No. 16 Tahun 1997 tentang Perubahan Hak Milik menjadi Hak Guna Bangunan atau Hak Pakai dan Hak Guna Bangunan menjadi Hak Pakai. ${ }^{14}$

Menurut pendapat penulis setelah permohonan pendaftaran perubahan Hak Milik menjadi Hak Pakai tersebut dengan dasar akta risalah lelang yang dimiliki oleh warga negara asing, maka untuk selanjutnya Hak Pakai tersebut harus didaftarkan pada Kantor Pertanahan Kabupaten/ Kota untuk memenuhi asas publisitas bagi kepentingan pemegang haknya yakni orang asing tersebut. Dalam hal ini juga penulis berpendapat bahwa dalam prosedur perubahan hak milik menjadi hak pakai yang dilakukan oleh Warga negara Asing berdasarkan Akta Risalah Lelang mengacu pada Keputusan Menteri Agraria/ Kepala Badan Pertanahan Nasional No. 16 Tahun 1997 tentang Perubahan Hak Milik menjadi Hak Guna Bangunan atau Hak Pakai dan Hak Guna Bangunan menjadi Hak Pakai yang dikarenakan belum adanya aturan yang secara khusus mengatur mengenai perubahan hak milik menjadi hak pakai bagi Warga negara Asing, dimana ketentuan tersebut merupakan kekhususan untuk perubahan hak milik menjadi hak pakai dengan obyek tanah yang dikuasai oleh warga negara asing.

Penjelasan ketentuan pengaturan yang terdapat pada UUPA khususnya tentang kepemilikan dan penguasaan tanah dengan adanya bangunan rumah di atasnya bagi

\footnotetext{
${ }^{14}$ Wawancara dengan Kepala Sub seksi Hak Tanah dan Penetapan tanah pada Kantor Badan Pertanahan Nasional Kota Mataram pada hari Rabu tanggal 9 Mei tahun 2017
} 
warga negara asing atau badan hukum asing di Indonesia tidak diatur secara spesifik dan terperinci, akan tetapi, warga negara asing dapat untuk memiliki rumah dengan status hak pakai. Ketentuan ini berdasarkan adanya prinsip atau asas yang dikenal dengan nama asas pemisahan horizontal yang artinya bahwa bangunan dan tanaman bukan merupakan bagian dari tanah yang bersangkutan. Maka dari itu penguasaan yang dapat dimiliki oleh warga negara asing terhadap bangunan rumah yang berada pada obyek tanah, tentunya dalam hal ini negara telah menjamin yang diatur dalam ketentuan Peraturan Pemerintah Republik Indonesia Nomor 103 Tahun 2015 tentang Pemilikan Rumah Tempat Tinggal atau Hunian Oleh Orang Asing Yang Berkedudukan di Indonesia yang diundangkan pada tanggal 28 Desember tahun 2015. Khusus berkaitan dengan orang asing yang dapat memiliki rumah untuk tempat tinggal atau hunian dengan Hak Pakai adalah orang asing yang berkedudukan di Indonesia yang keberadaannya memberikan manfaat melakukan usaha, bekerja, atau berinvestasi di Indonesia, demikian Pasal 1 ayat (1) PP 103/2015 jo Pasal 2 ayat (1) Peraturan Menteri Hukum dan Hak Asasi Manusia Republik Indonesia Nomor 23 tahun 2016 tentang Orang Asing atau Ahli Waris yang Merupakan orang asing sebagai pemilik Rumah Tempat Tinggal atau Hunian yang tidak lagi Berkedudukan di Indonesia (Permenhukham 23/2016) ${ }^{15}$

Berdasarkan ketentuan Pasal 11 Peraturan Pemerintah Republik Indonesia Nomor 103 Tahun 2015 tentang Pemilikan Rumah Tempat Tinggal atau Hunian Oleh Orang Asing Yang Berkedudukan Di Indonesia yang menyatakan bahwa: "Ketentuan lebih kanjut mengenai tata cara pemberian, pelepasan, atau pengalihan hak

${ }^{15}$ Herlien Budiono, Perjanjian Nominee berkaitan dengan Peraturan Pemerintah Nomor 103 Tahun 2015 dan akibat Hukumnya menurut Sistem Hukum Positif di Indonesia, Makalah yang dibawakan pada Seminar Internasional, Bali, 19 November 2016, halaman 3 atas pemilikan rumah tempat tinggal atau hunian oleh orang asing diatur dengan Peraturan Menteri/ Kepala Badan yang menyelenggarakan urusan pemerintahan di bidang agraria". Pemerintah melalui Menteri Agraria dan tata ruang/kepala Badan Pertanahan nasional Republik Indonesia telah mengeluarkan peraturan terbaru yakni Peraturan Menteri Agraria dan Tata Ruang/ Kepala Badan Pertanahan Nasional Republik Indonesia Nomor 29 Tahun 2016 mengenai tata cara pemberian, pelepasan, atau pengalihan atas pemilikan rumah tempat tinggal atau hunian oleh orang asing yang berkedudukan di Indonesia. Telah dijelaskan mengenai perolehan penguasaan rumah hunian bagi warga negara asing dengan status hak pakai yakni tepatnya diatur pada pasal 6 tentang Terjadinya Hak Pakai karena Subyek Hak Orang Asing yang menyatakan bahwa :

1) Rumah tempat tinggal yang dimiliki oleh Orang Asing di atas tanah Hak Milik atau Hak Guna Bangunan karena jual beli, hibah, tukar menukar, dan lelang, serta cara lain yang dimaksudkan untuk memindahkan hak atastanah, maka tanah Hak Milik atau Hak Guna Bangunan tersebut menjadi Tanah Negara yang langsung diberikan dengan perubahan menjadi Hak Pakai kepada Orang Asing yang bersangkutan.

2) Sarusun yang dibangun di atas Hak Guna Bangunan atau Hak Pengelolaan yang dimiliki oleh Orang Asing karena jual beli, hibah, tukar menukar, dan lelang, serta cara lain yang dimaksudkan untuk memindahkan hak, maka Hak Milik Atas Satuan Rumah Susun langsung diberikan denganperubahanmenjadiHakPakaiAtas Satuan RumahSusun kepada Orang Asing yang bersangkutan.

3) Pejabat Pembuat Akta Tanah membuat akta pemindahan hak, dan Pejabat Lelang membuataktarisalahlelang, atasHakMilik atau Hak Guna Bangunan untuk rumah 
Widia Ulan Dini, Sudiarto, Aris Munandar|Status Hukum Penguasaan Hak Atas Tanah Oleh........

tempat tinggal dan Hak Milik Atas Satuan

Rumah Susun sebagaimana dimaksud pada ayat (1) dan ayat (2) kepada Orang Asing.

Hak pakai dipahami sebagai hak yang diberi kekhususan sifat atau peruntukan penggunaan tanahnya atau atas pertimbangan dari sudut penggunaan tanahnya dan/atau penggunanya yang tidak dapat diberikan dengan HM, HGU, atau HGB karena Hak Pakai bukanlah merupakan hubungan yang penuh antara hak tersebut dan objek yang dihaki. Sesuai ketentuan UUPA Warga Negara asing berhak untuk memiliki Hak Pakai untuk peruntukan tanah di Indonesia, tetapi bukan Hak Milik. Status Hak Pakai ini diberikan kepada Warga Negara Asing dan menjadi fenomena hukum yang tidak memberikan kepastian atas kepemilikan tanah di Indonesia.

Berdasarkan penjelasan di atas, jika dikaitkan dengan Teori Kepastian Hukum menurut Peter Mahmud Marzuki yang menyatakan bahwa:

"Kepastian hukum mengandung dua pengertian, yaitu, pertama adanya aturan yang bersifat umum membuat individu mengetahui perbuatan apa yang boleh atau tidak boleh dilakukan, dan kedua, berupa keamanan hukum bagi individu dari kesewenangan pemerintah karena adanya aturan yang bersifat umum itu individu dapat mengetahui apa saja yang boleh dibebankan atau dilakukan oleh negara terhadap individu. Kepastian hukum bukan hanya berupa pasal-pasal dalam undang-undang, melainkan juga adanya konsistensi dalam putusan hakim yang lainnya untuk kasus serupa yang telah diputus." 16

Warga Negara Asing sebagai pembeli obyek hak Tanggungan dengan status tanah

${ }^{16}$ Peter Mahmud Marzuki, Pengantar Ilmu Hukum, Kencana Pranada Media Group, Jakarta, 2008, Hlm 158. hak milik atas tanah melalui Pelelangan harus melakukan prosedur Perubahan Hak sesuai dengan ketentuan Keputusan Menteri Agraria/ Kepala Badan Pertanahan Nasional No. 16 Tahun 1997 tentang Perubahan Hak Milik menjadi Hak Guna Bangunan atau Hak Pakai dan Hak Guna Bangunan menjadi Hak Pakai. Dengan demikian yang dilakukan oleh Warga Negara Asing telah sesuai dengan teori Kepastian hukum yang menyatakan bahwa individu yakni warga negara asing mengetahui perbuatan apa yang boleh atau tidak boleh dilakukan sesuai dengan ketentuan peraturan perundangundangan yang berlaku, sehingga status Hukum Penguasaan Hak atas tanah bagi Warga Negara Asing yang memperoleh hak milik atas tanah obyek hak Tanggungan dari suatu pelelangan yakni Warga Negara Asing hanya diberikan sebatas pada Hak Pakai saja, hal itu karena Warga Negara Asing merupakan Subyek yang tidak berhak untuk memperoleh Hak Milik atas Tanah di Indonesia sebagiamana ketentuan didalam Pasal 21 dan 26 UUPA yang mengandung asas Nasionalitas

\section{SIMPULAN}

Berdasarkan hasil penelitian diatas, maka dapat ditarik kesimpulan sebagai berikut :

Bahwa akta risalahlelangyang dibuatoleh Pejabat Lelang dapat dijadikan sebagai alat bukti untuk peralihan hak milik atas tanah bagi warga negara asing di Instansi Badan Pertanahan Nasional, tentunya kedudukan akta risalah lelang bagi warga negara asing tersebut sesuai dengan ketentuan pasal 41 Peraturan Pemerintah Nomor 24 Tahun 1997 tentang Pendaftaran Tanah.

Bahwa status hukum penguasaan tanah yang diberikan bagi warga negara asing jika memperoleh tanah melalui pelelangan yakni warga negara asing tersebut dapat menguasai tanah yang diperolehnya dengan status penguasaan hak pakai. Tentunya 
status penguasaan tanah dengan hak pakai atas nama warga negara asing terlebih dahulu harus dilakukan dengan prosedur perubahan hak sesuai dengan ketentuan Pasal 2 Keputusan Menteri Agraria/ Kepala Badan Pertanahan Nasional Nomor 16 Tahun 1997 tentang Perubahan Hak Milik menjadi Hak Guna Bangunan atau Hak Pakai dan Hak Guna Bangunan menjadi Hak Pakai tersebut dan penguasaan tanah dengan hak pakai bagi warga negara asing memiliki jangka waktu tertentu, yang mana jika jangka waktu tersebut telah habis maka dapat diperbaharui sesuai dengan ketentuan peraturan Perundang-Undangan yang berlaku. Namun jika warga negara asing memperoleh rumah tempat tinggal diatas tanah hak milik melalui pelelangan maka secara langsung akan diberikan perubahan menjadi hak pakai bagi warga negara asing sesuai dengan ketentuan Pasal 6 Peraturan Menteri Agraria Dan Tata Ruang/Kepala Badan Pertanahan Nasional Republik Indonesia Nomor 29 Tahun 2016 Tentang Tata Cara Pemberian, Pelepasan, atau Pengalihan Hak Atas Pemilikan Rumah Tempat Tinggal Atau Hunian Oleh Orang Asing Yang Berkedudukan di Indonesia.

\section{DAFTAR PUSTAKA}

Budiono Herlien, Perjanjian Nominee berkaitan dengan Peraturan Pemerintah Nomor 103 tahun 2015 dan akibat Hukumnya menurut Sistem Hukum Positif di Indonesia.

Harsono Boedi, 2008, Hukum Agraria Indonesia, Sejarah Pembentukan Undang-Undang Pokok Agraria, isi dan pelaksanaannya, Djambatan, Jakarta.

Rosandi, Baiq Henni Paramita. "Akibat Hukum Jual Beli Hak Atas Tanah Yang Belum Didaftarkan." Jurnal IUS (Kajian Hukum dan Keadilan) 4.3 (2016).

Marzuki Peter Mahmud,2008, Pengantar Ilmu Hukum, Kencana Pranada
Media Group, Jakarta.

Mulyadi Kartini dan Gunawan Wijaya, 2007, Hak-Hak Atas Tanah-Seri Hukum Harta Kekayaan, Kencana, Jakarta.

Santoso Urip, 2013, Pendaftaran dan Peralihan Hak Atas Tanah, Kencana, Prenada Media Group.

Sumardjono Maria S.W., 2001, Kebijakan Pertanahan, Antara Regulasi dan Implementasi, Kompas, Jakarta.

Sutardjo, 1994, Pelelangan Dalam Rangka Eksekusi Oleh Pengadilan Negeri dan Pelelangan Oleh PUPN serta Aspek-Aspek Hukumnya Yang Timbul Dalam Praktek, Jakarta.

Soeromihardjo Soedjarwo,2009,Mengkritisi Undang-Undang Pokok Agraria, Cerdas Pustaka, Jakarta.

Usman Rachmadi, 2016, Hukum Lelang, Sinar Grafika, Jakarta. 